\title{
Leaf development and growth of selected sugarcane clones in a subtropical environment
}

\author{
Nereu Augusto Streck ${ }^{(1)}$, Joana Graciela Hanauer ${ }^{(1)}$, Luana Fernandes Gabriel(1), \\ Taise Cristine Buske ${ }^{(1)}$ and Josana Andréia Langner ${ }^{(1)}$
}

(1)Universidade Federal de Santa Maria, Avenida Roraima, 1000, CEP 97105-900 Santa Maria, RS, Brazil. E-mail: nstreck2@yahoo.com.br, joana2hanauer@yahoo.com.br, Ihuanynha@yahoo.com.br, taisebuske@hotmail.com, josana.langner@yahoo.com.br

\begin{abstract}
The objective of this work was to compare phyllochron and leaf area on individual stalks of selected sugarcane (Saccharum officinarum) clones grown in a subtropical environment. A two-year field experiment was carried out in Santa Maria, RS, Brazil, during the 2007/2008 and 2008/2009 growing seasons. Three sugarcane clones were used: IAC 822045 (early), SP 711406 (median) and CB 4176 (late), in a complete randomized block design, with four replications. Expanded leaf and total leaf (tips) number were determined, and expanded leaf area was measured. The phyllochron $\left({ }^{\circ} \mathrm{C}\right.$ day leaf $\left.{ }^{-1}\right)$ based on expanded and tip leaf number was estimated, using $10^{\circ} \mathrm{C}$ as base temperature. Allometric relationships between individual area and number of expanded leaves were fitted. Phyllochron was analysed as a four-factor experiment: clone, growing season, phyllochron phase, and phyllochron type. The early clone had the greatest potential for growing in a subtropical climate because of higher leaf output and leaf area.

Index terms: Saccharum officinarum, allometric relationships, biofuel, leaf area, leaf number.

\section{Desenvolvimento e crescimento foliar de clones de cana-de-açúcar em ambiente subtropical}

Resumo - O objetivo deste trabalho foi comparar o filocrono e a área foliar em colmos individuais de clones de cana-de-açúcar (Saccharum officinarum) cultivados em ambiente subtropical. Um experimento de campo foi conduzido em Santa Maria, RS, durante os anos agrícolas 2007/2008 e 2008/2009. Três clones de cana-de-açúcar foram usados: IAC 822045 (precoce), SP 711406 (médio) e CB 4176 (tardio), em blocos ao acaso, com quatro repetições. Foi medido o número de folhas expandidas e totais (pontas), além da área das folhas expandidas. $\mathrm{O}$ filocrono $\left({ }^{\circ} \mathrm{C}\right.$ dia folha $\left.{ }^{-1}\right)$, baseado no número de folhas expandidas e totais, foi estimado utilizando $10^{\circ} \mathrm{C}$ como temperatura base. Relações alométricas entre a área de folhas individual e o número de folhas expandidas foram ajustadas. $\mathrm{O}$ filocrono foi analisado considerando-se um experimento fatorial com quatro fatores: clone, ano agrícola, fase de filocrono e tipo de filocrono. O clone precoce tem maior potencial para cultivo em regiões subtropicais devido ao maior aparecimento de folhas e à maior área foliar.

Termos para indexação: Saccharum officinarum, relações alométricas, biocombustível, área foliar, número de folhas.

\section{Introduction}

There is an increasing concern about global warming as a consequence of burning of fossil fuels, leading to increasing interest in alternative fuels, especially renewable biofuels. Sugar and ethanol are the main products of sugarcane (Saccharum officinarum L.) plantations in tropical and subtropical regions. Anticipating an increasing worldwide demand for ethanol as a biofuel, Brazil is a world leader in sugarcane production, comprising an area of about 8 million ha currently grown with this crop (Instituto Brasileiro de Geografia e Estatística, 2010).

The Southern states of Brazil - Paraná, Santa Catarina and Rio Grande do Sul - have a subtropical climate where sugarcane is harvested annually in late fall and early winter and its initial growth from plant crops and ratoon crops occurs in early spring, when minimum temperatures rise above $10^{\circ} \mathrm{C}$. Rio Grande do Sul state is the southernmost area in Brazil, and sugarcane can be grown there for sugar and ethanol production. However, in this region sugarcane is currently grown mostly for home-made sugar products and for feeding animals in small farms (Maluf et al., 2008).

Plant development and growth are basic processes that define crop yield. Development refers to events during crop ontogeny including cell differentiation, organ initiation (organogenesis) and appearance (morphogenesis), and crop senescence, while growth

Pesq. agropec. bras., Brasília, v.45, n.10, p.1049-1057, out. 2010 
refers to increases in organ or whole-plant physical dimensions such as length, height, area and volume (Hodges, 1991; Wilhelm \& McMaster, 1995). Leaf development is characterized by the appearance of new leaves and the consequent increase in accumulated leaf number (LN) on a stem or on a whole-plant basis, whereas leaf growth is often measured as the increase in leaf area (LA). Therefore, leaf development and growth are critical in determining the canopy leaf area index (LAI) that intercepts solar radiation for photosynthesis that leads to the accumulation of biomass, which ultimately defines crop yield.

When sugarcane is grown in a subtropical climate, initial leaf development and growth in early spring is crucial for a quick full soil cover by the canopy, thus increasing the length of the growing period for maximum sucrose accumulation (Sinclair et al., 2004). The rate of appearance and the size of earliest leaves are the main traits that define a more rapid expansion of crop leaf area and target traits when screening sugarcane clones for high productivity in subtropical regions (Bonnett, 1998; Sinclair et al., 2004).

The warmest regions in Rio Grande do Sul represent a relatively new edge for expanding sugarcane plantations in Brazil, and studies on the performance of sugarcane clones in this region, particularly related to leaf development and growth traits, are scarce, which constituted the rationale for this study.

Leaf appearance rate is often represented by its inverse, the phyllochron, defined as the time interval between the appearance of successive leaves on a stem, with unit of time per leaf(Wilhelm \& McMaster, 1995; Xue et al., 2004). As the rate of leaf appearance in sugarcane is primarily caused by air temperature (Inman-Bamber, 1994; Campbell et al., 1998; Sinclair et al., 2004), time in the phyllochron concept is better measured in units of thermal time. Therefore, the phyllochron is the thermal time needed for each new leaf to appear, and has unit of ${ }^{\circ} \mathrm{C}$ day leaf ${ }^{-1}$ (Xue et al., 2004). The leaf area index increases as individual leaves expand and new leaves appear. Therefore, a mechanistic approach to describe leaf area growth is through allometric relationships between cumulative individual leaf area and cumulative leaf number (Pivetta et al., 2007; Maldaner et al., 2009). To fully resolve the leaf area dynamics in sugarcane grown in subtropical Brazil, comparing leaf development and growth parameters of different clones is crucial.
The objective of this study was to compare the phyllochron and leaf area on individual stalks of three selected sugarcane clones grown in a subtropical environment.

\section{Materials and Methods}

A two-year field experiment was carried out at the research area of the Departamento de Fitotecnia of the Universidade de Santa Maria, in Santa Maria, RS, Brazil $\left(29^{\circ} 43^{\prime} \mathrm{S}, 53^{\circ} 43^{\prime} \mathrm{W}\right.$, 95-m altitude) during the 2007/2008 and 2008/2009 growing seasons.

This location has a Cfa (Subtropical wet and warm) climate, according to the Köppen System (Kuinchtner \& Buriol, 2001). A typical agricultural timeline for sugarcane crop in this location is to plant stalk cuts in early spring (September), vegetative growth takes place during the following months until the end of fall (late May), and harvest usually occurs in June and July (Maluf et al., 2008). The soil type at the experimental site is, according to the Brazilian Soil Taxonomy, a transition between the Unidade de Mapeamento São Pedro (Argissolo Vermelho distrófico arênico) and the Unidade de Mapeamento Santa Maria (Argissolo Bruno Acinzentado alítico típico) (Santos et al., 2006; Streck et al., 2008a).

Sugarcane clones used were: IAC 822045, an early clone from Instituto Agronômico de Campinas, São Paulo; SP 711406, a median clone from Copersucar, and CB 4176, a late clone from the Empresa de Pesquisa Agropecuária do Estado do Rio de Janeiro, Campos dos Goytacazes, RJ. These three clones were selected because they have distinct developmental rates and because they are widely grown in small farms in Rio Grande do Sul, as reported by local growers and extensionists.

Planting was carried out on November 5, 2007, and on September 18, 2008. The first planting date is late, whereas the second planting date is early for this location (Maluf et al., 2008). Using different planting dates in different years was a measure performed in order to foster development and growth of earliest leaves in different temperature and solar radiation conditions, which is important when comparing sugarcane clones for the traits initial rate of leaf appearance and leaf area.

The experimental design was a complete randomized block with four replications. Each replication was a $24 \mathrm{~m}^{2}$ plot composed of five $4.8 \mathrm{~m}$ long rows in an $\mathrm{E}-\mathrm{W}$ direction. 
Three-node stalk segments were planted at $20 \mathrm{~cm}$ depth in a plant spacing of $1.0 \times 0.8 \mathrm{~m}$, totaling 6 plants per row and 30 plants per plot. Fertilization rates at planting, in both years, followed local recommendations based on soil tests sampled in July 2007, and consisted of applying the fertilizer in furrows near to the stalks at rates that varied from 10.0 to $12.5 \mathrm{~kg} \mathrm{ha}^{-1}$ of $\mathrm{N}$, from 51.2 to $96.07 \mathrm{~kg} \mathrm{ha}^{-1}$ of $\mathrm{P}$, and from 40 to $50 \mathrm{~kg} \mathrm{ha}^{-1}$ of $\mathrm{K}$ depending on the location of the blocks. Additional nitrogen using urea was added as a side-dress application 90 days after planting, at rates that varied from 91.45 to $94.07 \mathrm{~kg} \mathrm{ha}^{-1}$ of $\mathrm{N}$. Weeds were manually controlled as needed throughout the experiment in order to minimize biotic stress by weed competition. Diseases and insects were not controlled because populations were below economic thresholds.

Emergence was measured in each plot by counting the number of emerged plants, on a daily basis, in all plots. The crop emergence date was considered as the day when $50 \%$ of the plants had emerged from the soil. Two weeks after emergence, four plants in two of the inner rows of each plot were randomly identified and tagged with colored wires. These plants were used to measure leaf appearance and leaf area. Leaf appearance was measured by weekly counting the number of leaves (from November, 2007, or October, 2008, until the following May) both on an expanded leaf number $\left(\mathrm{LN}_{\text {exp }}\right)$ and on a total or tip leaf number $\left(\mathrm{LN}_{\text {tip }}\right)$ basis. A leaf was assumed to be expanded when the ligule was visible and $\mathrm{LN}_{\text {tip }}$ was considered the $\mathrm{LN}_{\text {exp }}$ plus the number of leaf tips visible at the whorl. Blade length (L, from ligule to blade tip) and the widest blade width (W) of individual expanded leaves was measured after ligule appearance, and leaf area $\left(\mathrm{LA}, \mathrm{cm}^{2}\right)$ of these expanded leaves was calculated as: $\mathrm{LA}=\mathrm{f}(\mathrm{LxW})$, where $\mathrm{f}$ is a shape factor, assumed as 0.72 (Sinclair et al., 2004).

Daily minimum and maximum air temperatures were measured with a standard meteorological station located $200 \mathrm{~m}$ from the plots. Daily values of thermal time (TT, ${ }^{\circ} \mathrm{C}$ day) were calculated according to Rosa et al. (2009): $\mathrm{TT}=(\mathrm{T}-\mathrm{Tb}) \times 1$ day, where $\mathrm{T}$ is the mean daily air temperature, calculated from the average of daily minimum and maximum air temperatures, and $\mathrm{Tb}$ is the base temperature for leaf temperature in sugarcane, assumed as $10^{\circ} \mathrm{C}$ (Sinclair et al., 2004). The accumulated thermal time (ATT, ${ }^{\circ} \mathrm{C}$ day) from emergence was calculated by accumulating TT, i.e., $\mathrm{ATT}=\sum \mathrm{TT}$.
The $\mathrm{LN}_{\text {exp }}$ and $\mathrm{LN}_{\text {tip }}$ were linearly regressed against ATT, for each tagged plant. The phyllochron $\left({ }^{\circ} \mathrm{C}\right.$ day leaf ${ }^{-1}$ ) based on expanded leaf number $\left(\mathrm{PHYL}_{\text {exp }}\right.$ ) and on tip leaf number $\left(\mathrm{PHYL}_{\text {tip }}\right)$ was estimated as the inverse of the slope of the linear regressions, respectively (Xue et al., 2004; Streck et al., 2009). Previous studies have reported that in field-grown sugarcane the first leaves produced on the stalk appear at a higher rate than later leaves, with a typical biphasic linear response to ATT (Inman-Bamber, 1994; Bonnett, 1998; Sinclair et al., 2004). The break point of the biphasic linear response of LN against ATT has been reported to vary from 10 to 15 leaves (Inman-Bamber, 1994; Bonnett, 1998; Sinclair et al., 2004). Therefore, in addition to calculating a single phyllochron for the entire growing season $\left(\mathrm{PHYL}_{\text {entire }}\right)$, two other phases of the phyllochron $\mathrm{PHYL}_{\exp }$ and PHIL $_{\text {tip }}$ were also calculated: for the first 15 leaves $\left(\mathrm{PHYL}_{\text {early }}\right)$ and for the remaining leaves $\left(\mathrm{PHYL}_{\text {late }}\right)$. The one-single-phyllochron $\left(\mathrm{PHYL}_{\text {entire }}\right)$ analysis was kept for comparison with the results in Sinclair et al. (2004), who reported $\mathrm{PHYL}_{\text {entire }}$ values for four sugarcane clones grown in some locations in Florida, USA, where the climate is similar to Santa Maria, Brazil.

A four-factor analysis of variance (ANOVA) was performed to test the effect of the following main effects and associated interactions on the phyllochron: clone (three levels), growing season (two levels), phyllohcron phase (three levels: $\mathrm{PHYL}_{\text {entire }}$ PHYL $\mathrm{P}_{\text {early, }}$ and $\mathrm{PHYL}_{\text {late }}$ ), and phyllochron type (two levels: PHYL $_{\text {exp }}$ nad PHYL $_{\text {tip }}$ ). Phyllochron means were distinguished by the Tukey test at $5 \%$ probability. For this analysis, the phyllochrons of each plant were averaged in each replication (four tagged plants). Statistical analysis was performed using the SOC software.

Allometric relationships between individual area of expanded leaves $\left(\mathrm{LA}_{\exp }\right.$ ) and $\mathrm{LN}_{\exp }$ were tested by fitting the data to a power function: $y=a x^{b}$, where $y$ is the estimated $\mathrm{LA}_{\text {exp }}, \mathrm{x}$ is the $\mathrm{LN}_{\text {exp }}$, and $\mathrm{a}$ and $\mathrm{b}$ are empirical coefficients (Pivetta et al., 2007; Maldaner et al., 2009). Because of a severe weather event on January 8, 2008 with heavy hail and strong winds (gusts up to $31.4 \mathrm{~m} \mathrm{~s}^{-1}$ ) that caused damage to leaves 10 to 15 , the allometric relationships between LA and $\mathrm{LN}$ were fitted only for $\mathrm{LN}<10$ (early and late clones) or $\mathrm{LN}<12$ (median clone) in the 2008/2009 growing season. The hail did not affect leaf appearance, so the phyllochron analysis for the whole growing season in the 2008/2009 growing season was kept as well.

Pesq. agropec. bras., Brasília, v.45, n.10, p.1049-1057, out. 2010 


\section{Results and Discussion}

Meteorological conditions during the development and growth of earliest leaves were different in the two years (Figure 1). The first five leaves appeared and expanded under higher temperatures in 2007, when maximum temperature ranged from 30 to $35^{\circ} \mathrm{C}$, and solar radiation from about 10 to $25 \mathrm{MJ} \mathrm{m}^{-2} \mathrm{day}^{-1}$, than in 2008, when maximum temperature ranged from about
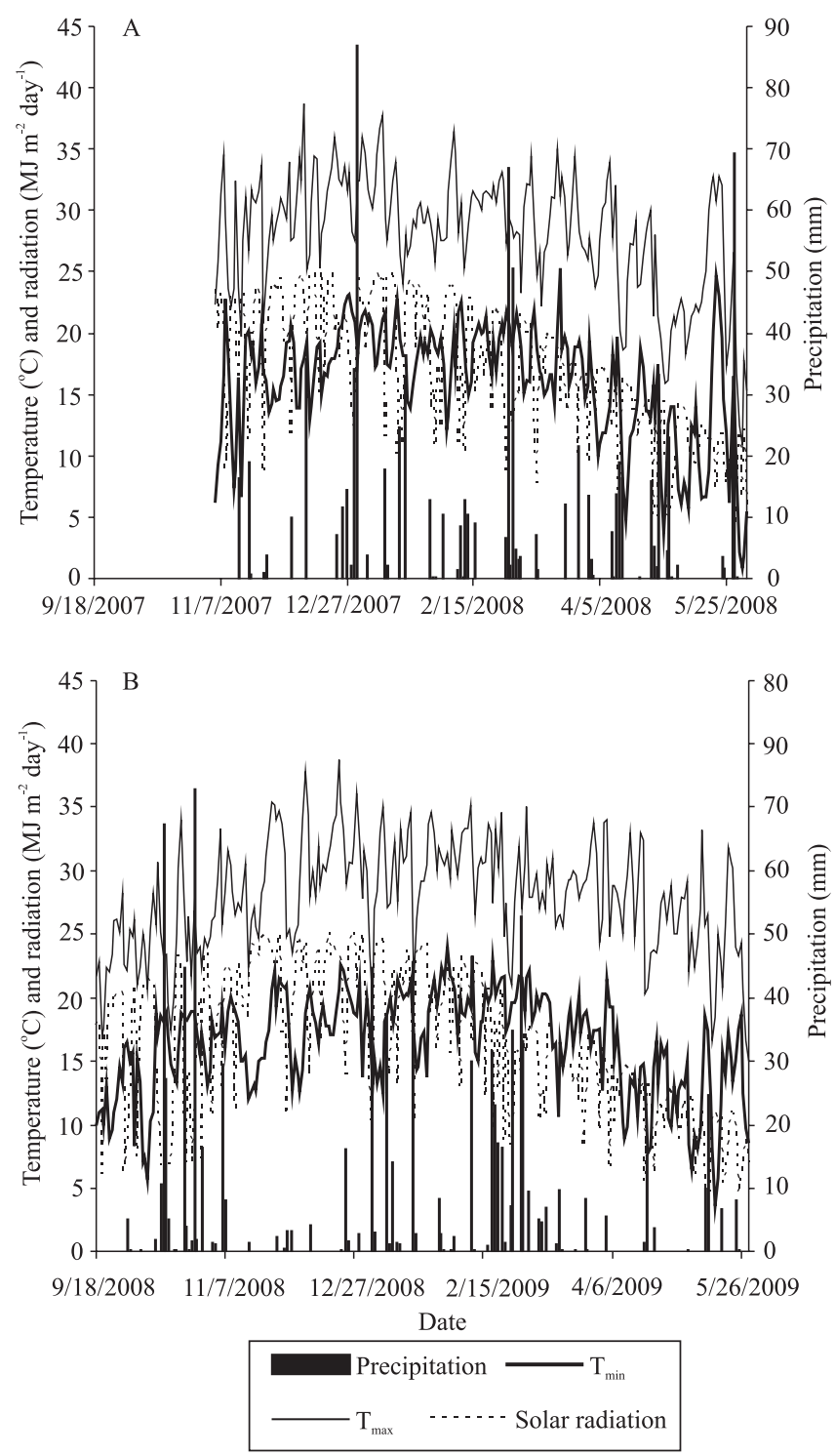

Figure 1. Daily values of minimum $\left(\mathrm{T}_{\min }\right)$ and maximum $\left(\mathrm{T}_{\max }\right)$ air temperatures, precipitation and incoming solar radiation flux density during the 2007/2008 (A) and 2008/2009 (B) growing seasons at Santa Maria, RS, Brazil.
20 to $25^{\circ} \mathrm{C}$ and solar radiation from about 5 to $23 \mathrm{MJ}$ $\mathrm{m}^{-2}$ day $^{-1}$.

Precipitation also had a different pattern throughout the two growing seasons: it was well distributed during the 2007/2008 growing season and a dry spell occurred in the 2008/2009 growing season with only $15 \mathrm{~mm}$, from November 8, 2008, to December 23, 2008. These distinct meteorological conditions during the two growing seasons are important for comparing leaf development and growth of the three sugarcane clones.

Increase in $\mathrm{LN}_{\text {exp }}$ and $\mathrm{LN}_{\text {tip }}$ over calendar days in sugarcane clone in the two growing seasons is presented in Figure 2. In the 2007/2008 growing season, both $\mathrm{LN}_{\text {exp }}$ and $\mathrm{LN}_{\text {tip }}$ were slightly higher in the median clone for the first 15 leaves $\left(\mathrm{LN}_{\text {exp }}\right)$ and 17 leaves $\left(\mathrm{LN}_{\text {tip }}\right)$ whereas for later leaves $\mathrm{LN}_{\text {exp }}$ and $\mathrm{LN}_{\text {tip }}$ were higher in the early clone. In the $2008 / 2009$ growing season, $\mathrm{LN}_{\text {exp }}$ and $\mathrm{LN}_{\text {tip }}$ were higher in the median clone for the first 10 and 12 leaves, respectively, and for the remaining of the growing period $\mathrm{LN}_{\text {exp }}$ and $\mathrm{LN}_{\text {tip }}$ was greater in the early clone. The $\mathrm{LN}_{\exp }$ and $\mathrm{LN}_{\text {tip }}$ were consistently lower in the late clone in both growing seasons. When time was measured as thermal time, variations of $\mathrm{LN}_{\text {exp }}$ and $\mathrm{LN}_{\text {tip }}$ from one week to the other observed in Figure 2 were minimized, confirming previous reports with several grasses (Wilhelm \& McMaster, 1995; Xue et al., 2004; Streck et al., 2009), including sugarcane (Inman-Bamber, 1994; Sinclair et al., 2004), that thermal time in plants is a better time descriptor than calendar days.

The increase in $\mathrm{LN}_{\exp }$ and $\mathrm{LN}_{\text {tip }}$ with thermal time could be fitted to a single general linear trend, but a close inspection of the data revealed that the relationship could be fitted to a biphasic linear response with a general break point at LN around 15. This break point in sugarcane has been reported in previous studies with different clones and in different locations, such as Australia, South Africa, and the USA (Inman-Bamber, 1994; Bonnet, 1998; Sinclair et al., 2004), and indicates that the phyllochron of the early leaves is lower than in the later leaves. The biphasic linear response of LN against thermal time in the three sugarcane clones in both growing season gives a basis for comparing not only a single one-season phyllochron $\left(\mathrm{PHYL}_{\text {entire }}\right)$, but also two phyllochrons separated by $\mathrm{LN}=15\left(\mathrm{PHYL}_{\text {early }}\right.$ and $\mathrm{PHYL}_{\text {late }}$ ) among sugarcane clones in this study (Table 1). 
The main effects of clone, growing season, phyllochron phase, and phyllochron type on the phyllochron were all significant at $5 \%$ probability. Among the main effects, mean square was the highest for phyllochron phase and the lowest for clone, suggesting that, in this study, phyllochron was more affected by the ontogeny of the crop and less by the genetic constitution. Significant
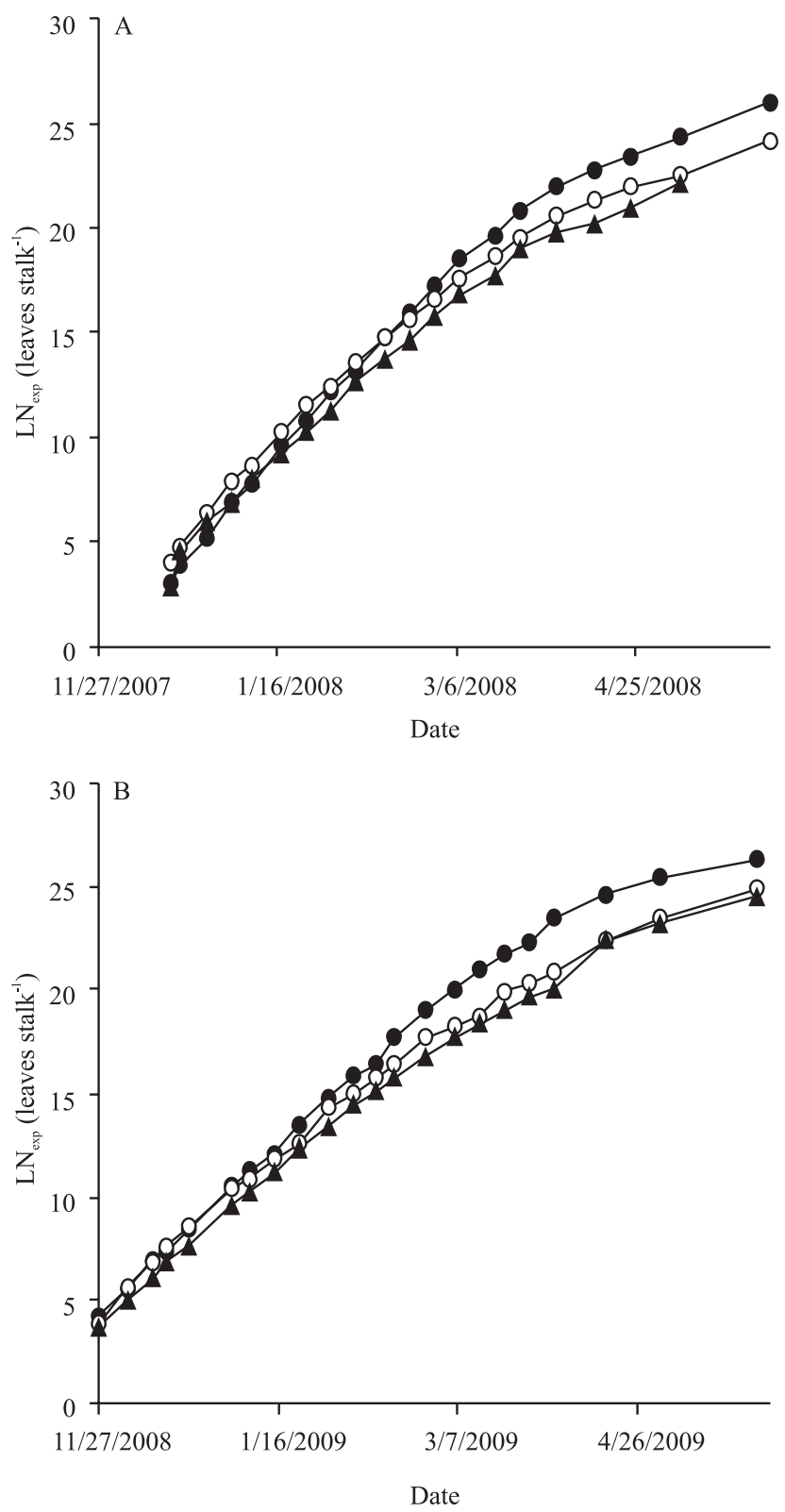

interactions were observed for clone $\mathrm{x}$ growing season, phyllochron type $\mathrm{x}$ phyllochron phase and clone $\mathrm{x}$ growing season $\mathrm{x}$ phyllochron phase. Therefore, statistical analysis was split accordingly, i.e. within clone, growing season, and phyllochron phase (Table 1).

Among clones, the early clone had lower $\mathrm{PHYL}_{\text {entire }}$ and $\mathrm{PHYL}_{\text {early }}$ both for expanded (PHYL $\mathrm{Pxp}_{\text {e }}$ ) and tip
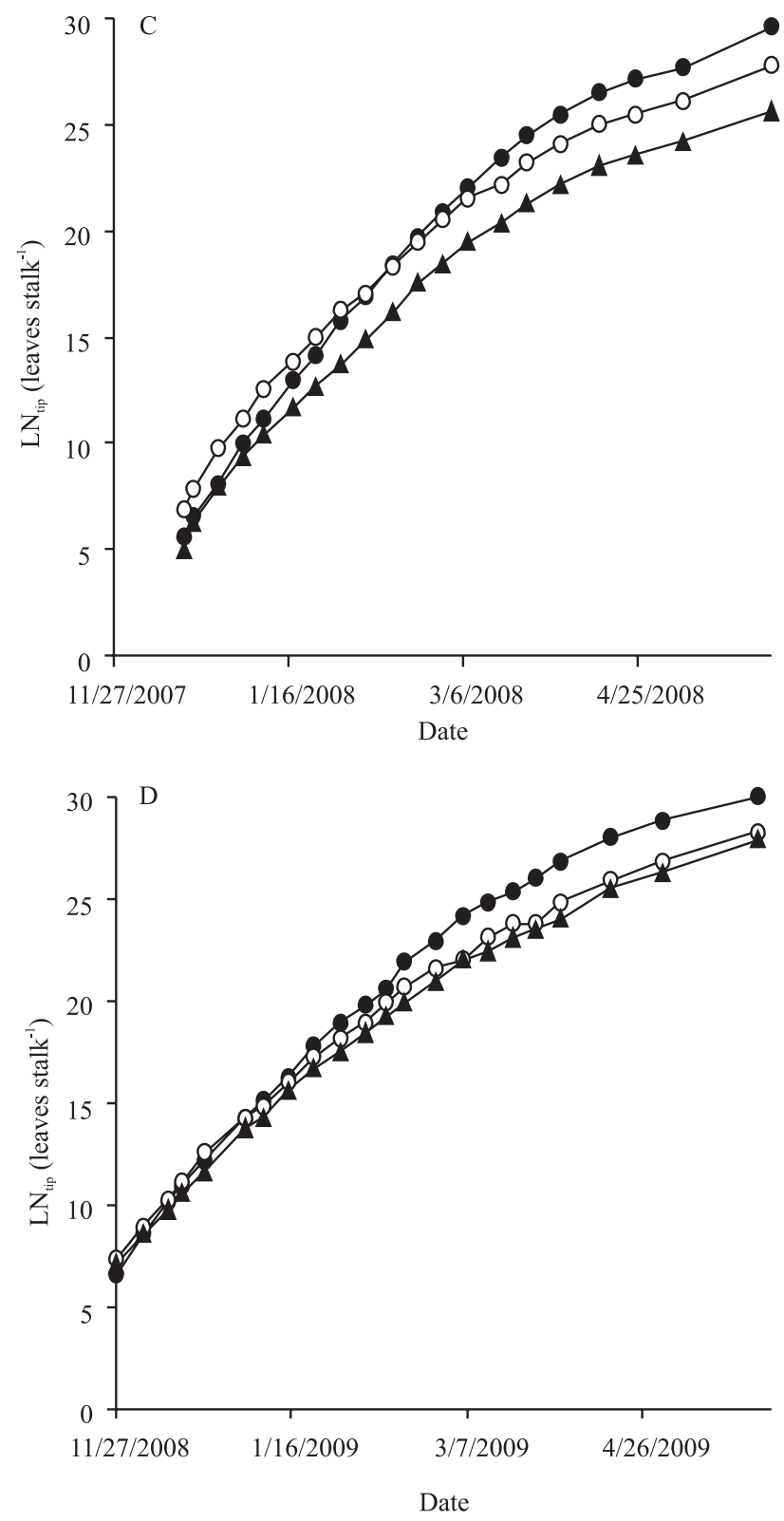

$$
\longrightarrow \text { Early } \multimap-\text { Median } \longrightarrow \text { Late }
$$

Figure 2. Accumulated expanded $\left(\mathrm{LN}_{\text {exp }}\right)$ and tip $\left(\mathrm{LN}_{\text {tip }}\right)$ leaf number on the main stalk of three sugarcane clones (Early $=\mathrm{IAC}$ 822045, Median $=$ SP 711406, and Late $=$ CB 4176) during the 2007/2008 (A, C) and 2008/2009 (B, D) growing seasons. Each point represents the mean of 16 plants. 
(PHYL tip $_{\text {) }}$ phyllochron type in the 2007/2008 growing season, while phyllochron phase did not differ among clones in the 2008/2009 growing season and for $\mathrm{PHYL}_{\text {late }}$ in the $2007 / 2008$ growing season (Table 1). These results indicate that the early clone had the highest leaf appearance rate in late planting dates (2007/2008 growing season), but in early planting dates (2008/2009 growing season) the leaf appearance rate is similar among the three clones.

Across growing seasons, the phyllochron phase (PHYL $L_{\text {entire, }}$ PHYL $\mathrm{L}_{\text {early, and }} \mathrm{PHYL}_{\text {late }}$ ) was lower or similar in the 2007/2008 growing season except for $\mathrm{PHYL}_{\text {early }}$ on an expanded leaf basis $\left(\mathrm{PHYL}_{\text {exp }}\right)$ of clone SP 711406 in the 2008/2009 growing season (Table 1). These results indicate that different years associated with different planting dates affect leaf appearance rates in these clones so that late plantings may accelerate leaf appearance on a thermal time basis. A possible hypothesis to explain these results is that the late planting date in the 2007/2008 growing season led to sugar plants developing leaves in higher temperatures right after emergence than in the early planting date in $2008 / 2009$. The non-linear response of leaf appearance to temperature has been blamed as a major cause of differences in thermal time for leaf appearance in several field grass crops, such as wheat (Xue et al., 2004), rice (Streck et al., 2008b), and maize (Streck et al., 2010), and this may also be the case in sugarcane.

Among phyllochron phases, phyllochron increased in the sequence $\mathrm{PHYL}_{\text {early }}>\mathrm{PHYL}_{\text {entire }}>\mathrm{PHYL}_{\text {late }}$ in the three clones, in the two growing seasons, both on expanded and tip leaf number (Table 1). These results indicate that early leaves, with break point at 15 leaves, appear faster than late leaves, confirming previous results from around the world (Inman-Bamber, 1994; Bonnet, 1998; Sinclair et al., 2004).

The interactions between clones involving phyllochron type $\left(\mathrm{PHYL}_{\text {exp }}\right.$ and $\left.\mathrm{PHYL}_{\text {tip }}\right)$ were not significant, and this is the reason why only two means are compared (Table 1). PHYL $\mathrm{L}_{\text {exp }}$ was higher than PHYL $_{\text {tip }}$, indicating an accumulation of unexpanded leaves at the whorl throughout the growing period, which is similar to maize (Streck et al., 2009).

Values of PHYL $\mathrm{L}_{\text {entire }}$ on an expanded LN basis in this study varied from 87.7 to $113.2^{\circ} \mathrm{C}$ day leaf ${ }^{-1}$. This range of phyllochron values is similar to the range of $87-118\left({ }^{\circ} \mathrm{C}\right.$ day leaf $\left.{ }^{-1}\right)$ reported by Sinclair et al. (2004) for four sugarcane clones grown in three locations in Florida, USA, and consistent with the values of $109-118^{\circ} \mathrm{C}$ day leaf ${ }^{-1}$ for two clones reported by Inman-Bamber (1994), indicating that

Table 1. Phyllochron $\left({ }^{\circ} \mathrm{C}\right.$ day leaf $\left.{ }^{-1}\right)$ on the main stalk of three sugarcane clones (Early= IAC 822045, Median $=$ SP 711406 , and Late $=\mathrm{CB} 4176)$ in two growing seasons, considering three phyllochron phases $\left(\mathrm{PHYL}_{\text {entire}}, \mathrm{PHYL}_{\text {early }}, \mathrm{PHYL}_{\text {late }}\right)$ and two phyllochron types $\left(\text { PHYL }_{\text {exp }}, \text { PHYL }_{\text {tip }}\right)^{(1)}$.

\begin{tabular}{|c|c|c|c|c|c|c|c|c|}
\hline \multirow[t]{2}{*}{ Clone } & \multicolumn{3}{|c|}{ PHYL $_{\exp }$} & \multirow[t]{2}{*}{ Mean } & \multicolumn{3}{|c|}{ PHYL $_{\text {tip }}$} & \multirow[t]{2}{*}{ Mean } \\
\hline & PHYL $_{\text {entire }}$ & PHYL $L_{\text {early }}$ & PHYL $_{\text {late }}$ & & PHYL $_{\text {entire }}$ & PHYL $_{\text {early }}$ & $\mathrm{PHYL}_{\text {late }}$ & \\
\hline & \multicolumn{8}{|c|}{$2007 / 2008$ Growing season } \\
\hline IAC 822045 & $87.7 \mathrm{bbA}^{*}$ & $81.5 \mathrm{bbB}$ & $120.4 \mathrm{aaA}$ & 96.5 & $84.7 \mathrm{bbB}$ & $75.7 \mathrm{babA}$ & $113.4 \mathrm{aaA}$ & 91.3 \\
\hline SP 711406 & 103.2abaA & $95.2 \mathrm{baA}$ & $125.2 \mathrm{aaA}$ & 107.9 & 101.1abaA & $85.1 \mathrm{baA}$ & $114.2 \mathrm{aaB}$ & 100.1 \\
\hline CB 4176 & $100.9 \mathrm{baA}$ & $78.0 \mathrm{cbB}$ & $137.3 \mathrm{aaA}$ & 105.4 & $100.7 \mathrm{baA}$ & $69.5 \mathrm{cbB}$ & $122.3 \mathrm{aaB}$ & 97.5 \\
\hline \multirow[t]{2}{*}{ Mean } & & & & 103.3 & & & & 96.3 \\
\hline & \multicolumn{8}{|c|}{$2008 / 2009$ Growing season } \\
\hline IAC 822045 & $108.8 \mathrm{baA}$ & $94.7 \mathrm{caA}$ & $129.2 \mathrm{aaA}$ & 110.9 & 109.3baA & $81.5 \mathrm{caA}$ & $131.3 \mathrm{aaA}$ & 107.4 \\
\hline SP 711406 & $106.9 \mathrm{baA}$ & $88.7 \mathrm{caA}$ & $131.7 \mathrm{aaA}$ & 109.1 & 106.6baA & $73.2 \mathrm{caA}$ & $132.0 \mathrm{aaA}$ & 103.9 \\
\hline CB 4176 & $113.2 \mathrm{baA}$ & $97.8 \mathrm{caA}$ & $132.9 \mathrm{aaA}$ & 114.6 & $113.4 \mathrm{baA}$ & $82.7 \mathrm{baA}$ & $136.4 \mathrm{aaA}$ & 110.8 \\
\hline Mean & & & & 111.5 & & & & 107.4 \\
\hline \multicolumn{4}{|l|}{ Mean } & $107.4 a^{* *}$ & & & & $101.8 b^{* *}$ \\
\hline \multicolumn{9}{|c|}{ 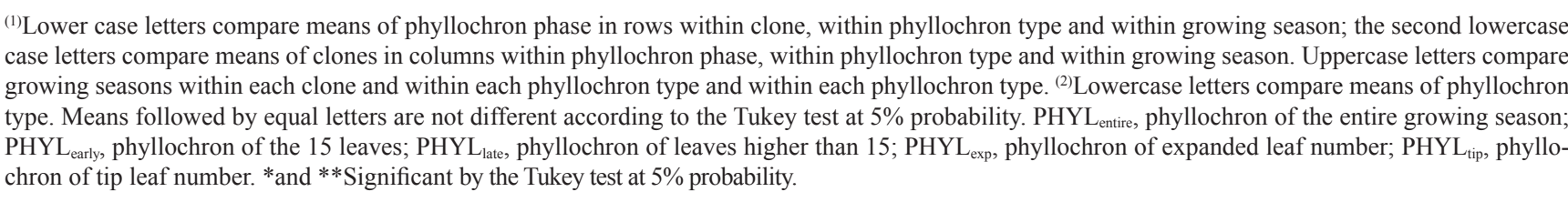 } \\
\hline
\end{tabular}

Pesq. agropec. bras., Brasília, v.45, n.10, p.1049-1057, out. 2010 
phyllochron is a conservative trait among sugarcane genotypes.

Allometric relationships between individual accumulated expanded LA and $\mathrm{LN}_{\exp }$ are presented in Figure 3, which compares clones in each growing season, and in Figure 4, which compares growing season in each clone. $\mathrm{LA}_{\exp }$ versus $\mathrm{LN}_{\text {exp }}$ data of the three clones fell into a general trend that follows a power function in both growing seasons (Figure $3 \mathrm{~A}$ and $3 \mathrm{~B}$ ). These results are in agreement with previous studies that surveyed other crops, such as tomato (Pivetta et al., 2007) and eggplant (Maldaner et al., 2009), suggesting that genotypes within the same species have a similar pattern of leaf growth response as a function of leaf development.
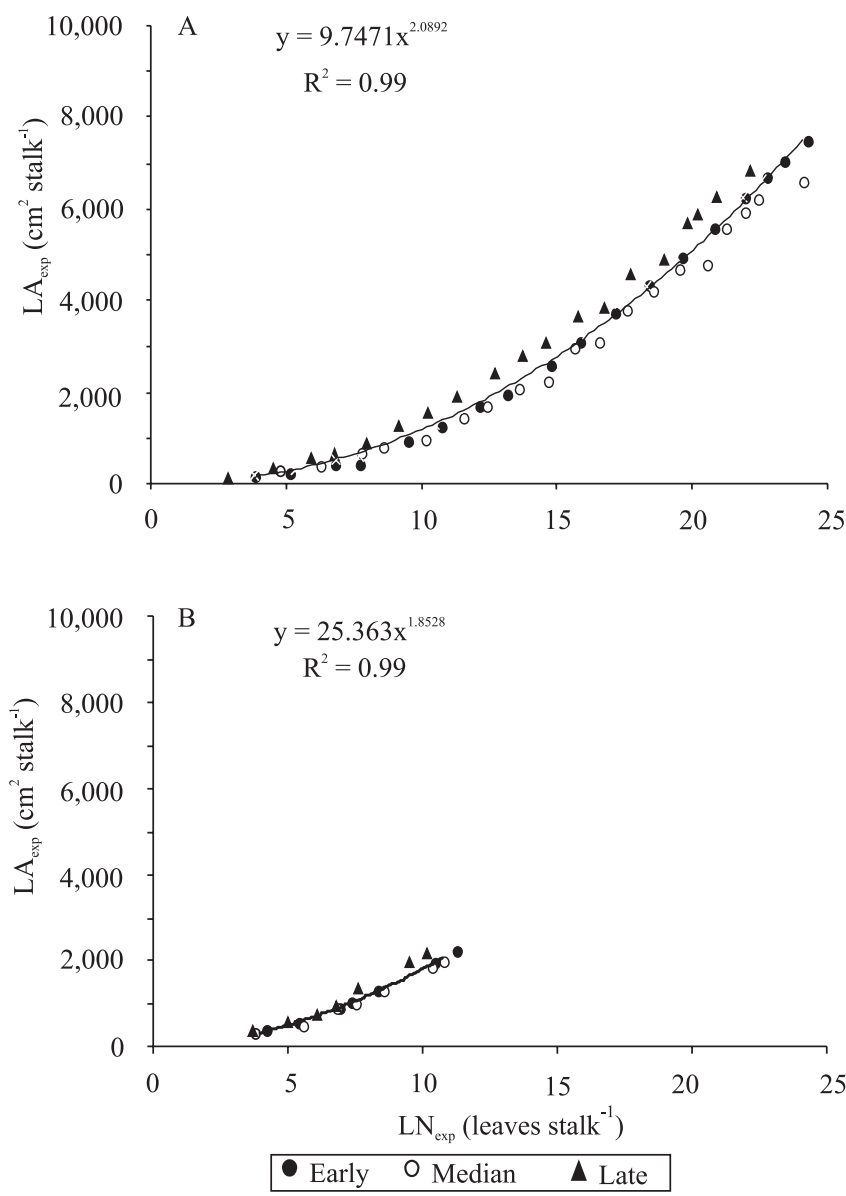

Figure 3. Allometric relationships between accumulated expanded leaf area $\left(\mathrm{LA}_{\text {exp }}\right)$ and accumulated expanded leaf number $\left(\mathrm{LN}_{\mathrm{exp}}\right)$ on the main stalk of three sugarcane clones: $\quad$ Early $=$ IAC 822045; Median $=$ SP 711406, and Late $=$ CB 4176, during the 2007/2008 (A) and 2008/2009 (B) growing seasons. Each point represents the mean of 16 plants.
Among growing seasons, area of individual leaves was greater in the 2008/2009 growing season in the three clones (Figure 4). The hypothesis to explain the difference in leaf area in the two
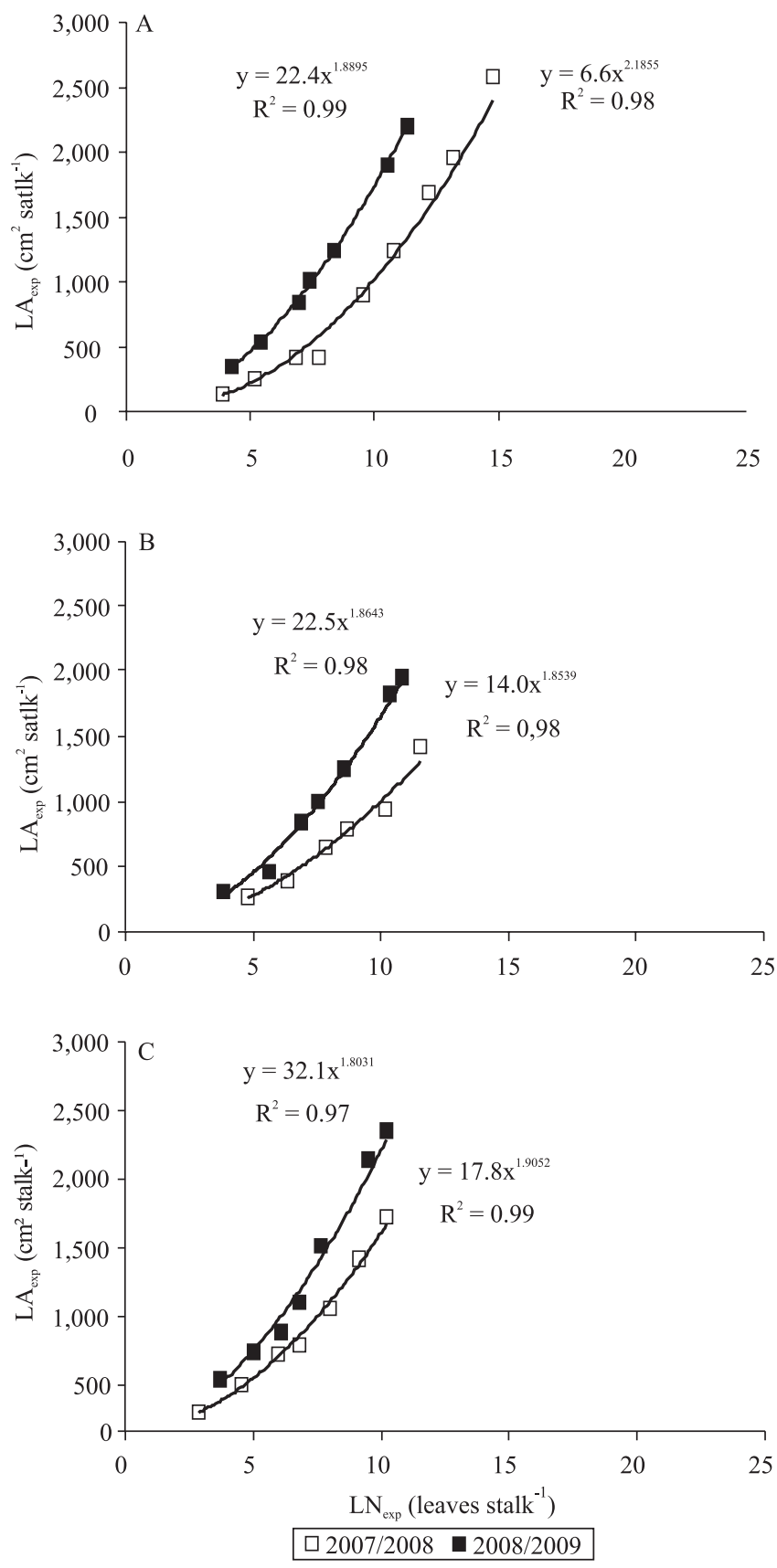

Figure 4. Relationship between accumulated expanded leaf area $\left(\mathrm{LA}_{\text {exp }}\right)$ and accumulated expanded leaf number $\left(\mathrm{LN}_{\text {exp }}\right)$ on the main stalk of three sugarcane clones: A, Early $=$ IAC 822045; B, Median $=$ SP 711406, and $C$, Late $=$ CB 4176, during two growing seasons $(2007 / 2008$ and 2008/2009). 
growing seasons is that the late planting date in the 2007/2008 growing season led the first 6-8 leaves to grow under higher temperatures, and beyond the optimum temperature, as they appeared in December 2007 and early January 2008, compared to the same leaves in the 2008/2009 growing season which appeared in October and November 2008 (Figures 1 and 2). These results indicate that early planting is a practical strategy to increase leaf area and potentially increase light interception by sugarcane grown in subtropical climates.

Even though the variation of $\mathrm{LA}_{\exp }$ as a function of $\mathrm{LN}_{\exp }$ of the three clones follows a general pattern, the leaf area of the early clone (IAC 822045) is consistently higher than the other two clones, in both growing seasons (Figure 3), indicating that the size of the early leaves is a trait that favors the early clone. The higher leaf expansion rate of the early clone is represented by the highest $b$ coefficient of the power function, in both years (Table 2). The median clone (SP 711406) showed the lowest individual leaf area in both years (Figure 3), although first leaves appeared sooner (Figure 2). The lower leaf area of the median clone is due to the narrower leaves of this clone. Using the allometric relationships between $\mathrm{LA}_{\exp }$ and $\mathrm{LN}_{\exp }$ for each clone (Table 2), the variation of $\mathrm{LA}_{\mathrm{exp}}$ over time in each growing season was calculated combining the area of individual leaves and leaf appearance rates during the growing period. The early clone produced consistently higher leaf area by the end of both growing seasons (Figure 5). Assuming an equal number of stalks per area, this clone has the greatest potential for the subtropical climate (Sinclair et al., 2004).

Table 2. Coefficients of the power function $\left(y=a x^{b}\right)$ for the allometric relationship between individual area of expanded leaves $\left(\mathrm{y}=\mathrm{LA}_{\text {exp }}\right)$ and expanded leaf number $\left(\mathrm{x}=\mathrm{LN}_{\text {exp }}\right)$ on the main stalk of three sugarcane clones (Early $=$ IAC 822045 , Median $=$ SP 711406, and Late $=$ CB 4176) in two growing seasons.

\begin{tabular}{lccccc}
\hline Clone & \multicolumn{2}{c}{$2007 / 2008$ Growing season } & & \multicolumn{2}{c}{$2008 / 2009$ Growing season } \\
\cline { 2 - 3 } \cline { 5 - 6 } & $\mathrm{a}$ & $\mathrm{b}$ & & $\mathrm{a}$ & $\mathrm{b}$ \\
\hline IAC 822045 & 6.019 & 2.2395 & & 22.436 & 1.8895 \\
SP 711406 & 8.541 & 2.1029 & & 22.579 & 1.8643 \\
CB 4176 & 16.894 & 1.9411 & & 32.179 & 1.8031 \\
\hline
\end{tabular}
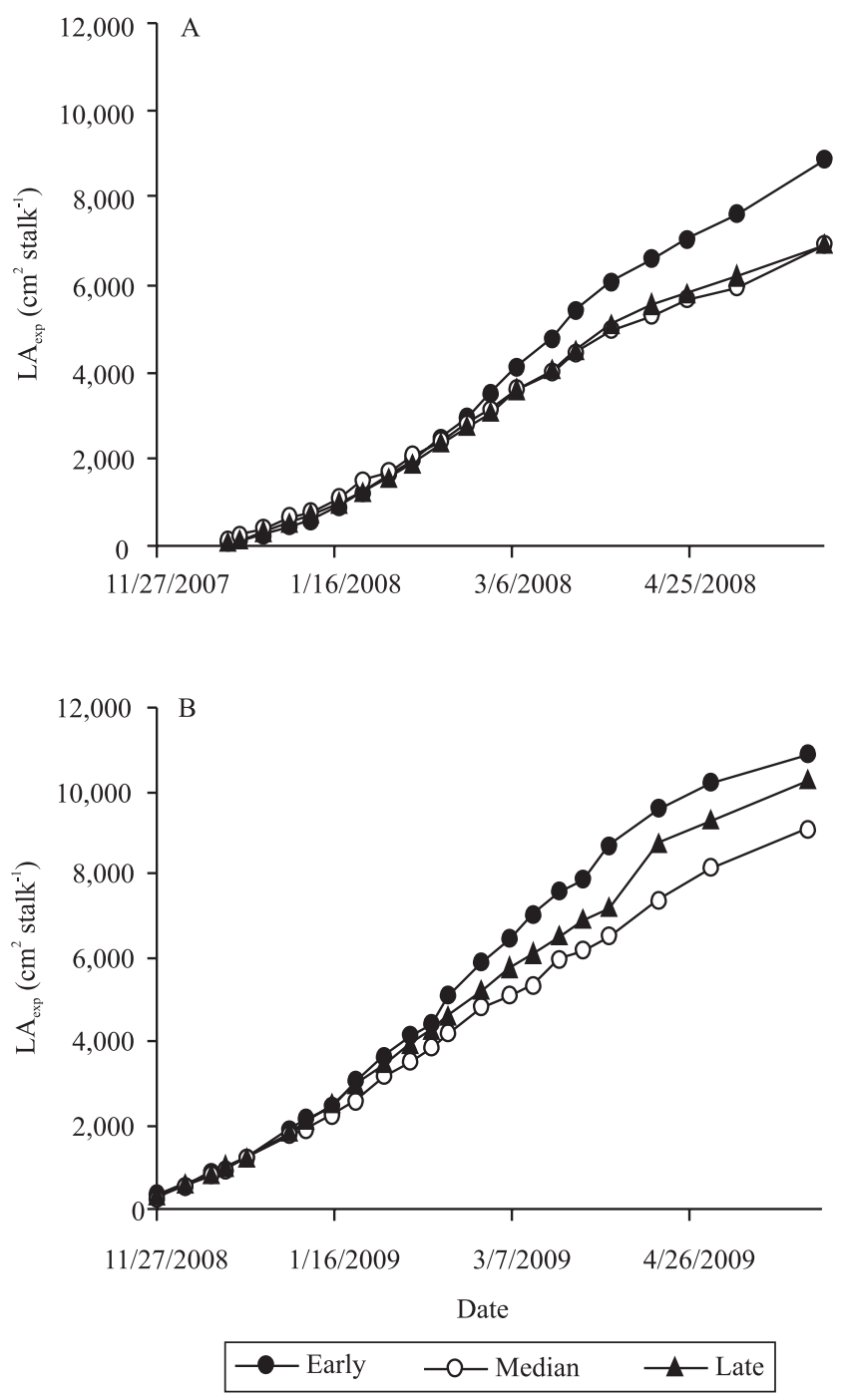

Figure 5. Accumulated expanded leaf area $\left(\mathrm{LA}_{\exp }\right)$ on the main stalk of three sugarcane clones (Early = IAC 822045, Median $=$ SP 711406, and Late $=\mathrm{CB}$ 4176) during the 2007/2008 (A) and 2008/2009 (B) growing seasons. Leaf area was calculated from accumulated expanded leaf number $\left(L_{\exp }\right)$ with a power function $\left(\mathrm{y}=\mathrm{ax} \mathrm{x}^{\mathrm{b}}\right)$ with coefficients a and $b$ fitted for each clone in each growing season shown in Table 2.

\section{Conclusions}

1. The early clone has higher leaf appearance rate in late planting.

2. Phyllochron is lower in late planting dates.

3. Early leaves appear at a higher rate than late leaves, with break point at 15 leaves.

4. The early clone has faster leaf area growth and the greatest potential for use in the subtropical climate. 


\section{References}

BONNETT, G.D. Rate of leaf appearance in sugarcane, including a comparison of a range of varieties. Australian Journal of Plant Physiology, v.25, p.829-834, 1998.

CAMPBELL, J.A.; ROBERTSON, M.J.; GROF, C.P.L. Temperature effects on node appearance in sugarcane. Australian Journal of Plant Physiology, v.25, p.815-818, 1998.

HODGES, T. Predicting crop phenology. Boston: CRC, 1991. $233 \mathrm{p}$.

INSTITUTO BRASILEIRO DE GEOGRAFIA E ESTATÍSTICA. Levantamento sistemático da produção agrícola. Disponível em: $<$ http://www.ibge.gov.br/home/estatistica/indicadores/ agropecuaria/lspa/lspa_200902_4.shtm.> Acesso em: 08 abr. 2010.

INMAN-BAMBER, N.G. Temperature and seasonal effects on canopy development and light interception of sugarcane. Field Crops Research, v.36, p.41-51, 1994.

KUINCHTNER, A.; BURIOL, G.A. Clima do Estado do Rio Grande do Sul segundo a classificação climática de Köppen e Thornthwaite. Disciplinarum Scientia, v.2, p.171-182, 2001.

MALDANER, I.; GUSE, F.I.; STRECK, N.A.; HELDWEIN, A.B.; LUCAS, D.D.P.; LOOSE, L.H. Filocrono, área foliar e produtividade de frutos de berinjela conduzidos com uma e duas hastes por planta em estufa plástica. Ciência Rural, v.31, p.671-677, 2009.

MALUF, J.R.T.; WESTPHALEN, S.L.; MATZENAUER, R.; MALUF, D.E. Zoneamento agroclimático atualizado para a cultura da cana-de-açúcar no estado do Rio Grande do Sul, visando à produção de açúcar e álcool. Porto Alegre: FEPAGRO, 2008. 78p. (FEPAGRO. Boletim técnico, 18).

PIVETTA, C.R.; TAZZO, I.F.; MAASS, G.F.; STRECK, N.A.; HELDWEIN, A.B. Emissão e expansão foliar em três genótipos de tomateiro (Lycopersicon esculentum Mill.). Ciência Rural, v. 37, p.1274-1280, 2007.
ROSA, H.T.; WALTER, L.C.; STRECK, N.A.; ALBERTO, C.M. Métodos de soma térmica e datas de semeadura na determinação de filocrono de cultivares de trigo. Pesquisa Agropecuária Brasileira, v.44, p.1374-1382, 2009.

SANTOS, H.G. dos; JACOMINE, P.K.T.; ANJOS, L.H.C. dos; OLIVEIRA, V.A. de; OLIVEIRA, J.B. de; COELHO, M.R.; LUMBRERAS, J.F.; CUNHA, T.J.F. (Ed.). Sistema brasileiro de classificação de solos. Rio de Janeiro: Embrapa Solos, 2006. $306 \mathrm{p}$.

SINCLAIR, T.R.; GILBERT, R.A.; PERDOMO, R.E.; SHINE JUNIOR, J.M.; POWELL, G.; MONTES, G. Sugarcane leaf area development under field conditions in Florida, USA. Field Crops Research, v.88, p.171-178, 2004.

STRECK, E.V.; KÄMPF, N.; DALMOLIN, R.S.D.; KLAMT, E.; NASCIMENTO, P.C. do.; SCHNEIDER, P.; GIASSON, E.; PINTO, L.F.S. Solos do Rio Grande do Sul. 2.ed. Porto Alegre: EMATER/RS, 2008a. 222p.

STRECK, N.A.; BOSCO, L.C.; LAGO, I. Simulating leaf appearance in rice. Agronomy Journal, v.100, p.490-501, 2008b.

STRECK, N.A.; GABRIEL, L.F.; BUSKE, T.C.; LAGO, I.; SAMBORANHA, F.K.; SCHWANTES, A.P. Simulating leaf appearance in a maize variety. Bioscience Journal, v.26, p.384-393, 2010.

STRECK, N.A.; LAGO, I.; SAMBORANHA, F.K.; GABRIEL, L.F.; SCHWANTES, A.P.; SCHONS, A. Temperatura base para aparecimento de folhas e filocrono da variedade de milho BRS Missões. Ciência Rural, v.39, p. 224-227, 2009.

WILHELM, W.W.; MCMASTER, G.S. Importance of the phyllochron in studying development and growth in grasses. Crop Science, v.35, p.1-3, 1995.

XUE, Q.; WEISS, A.; BAENZIGER, P.S. Predicting leaf appearance in field grown winter wheat: evaluating linear and non-linear models. Ecological Modelling, v.175, p.261-270, 2004.

Received on May 27, 2010 and accepted on September 2, 2010 